\title{
Bottom sediments of Lake Rotoma
}

\author{
CAMPBELL S. NELSON \\ Department of Earth Sciences \\ University of Waikato \\ Private Bag \\ Hamilton, New Zealand
}

\begin{abstract}
Lake Rotoma is a deep $(70-80 \mathrm{~m})$, oligotrophic, warm monomictic lake of volcanic origin with insignificant stream inflow and no clearly defined outflow. For at least 60 years up to 1972 the lake level fluctuated markedly about an overall rising trend of some $6-10 \mathrm{~m}$. Nearshore profiles are related to the prevailing wave climate superimposed upon the overall rising lake level, shelves being wider, less steep, and deeper about the more exposed eastern and southern shorelines. The outer portions of shelves extending well below modern storm wave base into waters as deep as $15-25 \mathrm{~m}$ are relict features from lower lake level stands. Sediments fine from sand-gravel mixtures nearshore to silts in basinal areas. Their composition reflects a composite provenance involving the lavas and tephras about the lake, as well as intralake diatom frustules and organic matter. The distribution pattern of surficial bottom sediments is an interplay between grains of both biological and terrigenous origin, supplied presently and in the past by a variety of processes, that have been dispersed either by the modern hydrodynamic regime or by former ones associated with lower lake levels. These interrelationships are structured by erecting 5 process-age sediment classes in the lake, namely neoteric, amphoteric, proteric, palimpsest, and relict sediments, analogous to categories postulated for sediments on oceanic continental shelves. Shortcore stratigraphy includes the Kaharoa (A.D. $\sim 1020$ ) and Tarawera (A.D. 1886) tephras. The rates of sedimentation of diatomaceous silts in basinal areas have more than doubled since the Tarawera eruption, indicating an overall increase in the fertility level of lake waters associated, perhaps, with recent farm development in the catchment.
\end{abstract}

Keywords Lake Rotoma; lakes; limnology; sediments; sedimentation; stratigraphy; morphology; sediment texture; sediment collections; sediment sampling; sediment transport; sediment distribution; bottom topography

Received 16 July 1981; accepted 18 November 1982

\section{INTRODUCTION}

Although much is known of the chemistry and biology of lakes in central North Island, New Zealand (e.g., Fish 1970; McColl 1972; Jolly \& Brown 1975; Flint 1977), little information is yet available on the texture and composition of the bottom sediments or the patterns and processes of sedimentation in these lakes. Because of the influence of sediment substrate on such diverse characteristics as sublacustrine slope stability (e.g., Irwin 1975), the nature and density of aquatic vegetation (e.g., Brown 1975), the geochemical environment at the lake floor (e.g.. Glasby 1973), and ultimately the trophic status of waters (e.g., McColl 1977; White et al. 1978), a sampling and analysis programme of bottom sediments of central North Island lakes has been started at the University of Waikato. To date, sediment characteristics are available for Lake Taupo (Lister 1978), Lake Matahina (Phillips \& Nelson 1981), Lake Rotoiti (Craig \& Nelson 1981), and Lake Rotoma, reported here.

Lake Rotoma (Fig. 1) is the easternmost of 16 lakes of primarily volcanic origin forming the Rotorua lakes system in the Rotorua district. However, unlike most Rotorua lakes, which are eutrophic, it remains essentially oligotrophic because of a combination of minimal inflows from hot springs and surface streams, the relatively small area $(38 \%)$ of drainage catchment in pasture, and the existence of uniformly deep $(70-80 \mathrm{~m})$ basins (McColl 1974).

\section{METHODS}

A working field sheet was constructed from Irwin's (1967) bathymetric map of Lake Rotoma. Bottom samples were collected in winter 1975 using a 5-Lcapacity Ekman-Berge grab sampler and a Model 202 Alpine piston corer with 4-cm-diameter PVC liner. Beach samples were scooped by trowel from the upper $2 \mathrm{~cm}$ of the shoreface. Sediment $\mathrm{pH}$ and Eh were measured immediately onboard using a probe-type combination $\mathrm{pH} / \mathrm{Eh}$ meter calibrated against standard solutions. Sample stations (Fig. 2) were positioned by intersection of several compass bearings to prominent features about the shoreline, and supplemented by bathymetric control using a Marlin DIR60 echo sounder. Structure within the top few metres of lake sediment was recorded using a $7 \mathbf{~ k H z}$ Raytheon seismic profiler in 3 across-lake 
transects (Fig. 2). Secchi disc measurements were made at most stations, and a single temperature profile was measured on 7 July 1975 with a reversing thermometer in the deepest $(83 \mathrm{~m})$ part of the lake, near Stn 58.

In the laboratory, samples were split, digested in $10 \% \mathrm{H}_{2} \mathrm{O}_{2}$ to remove and determine the percent by weight of organic matter, wet-sieved through $2 \mathrm{~mm}$ $(-1 \phi)$ and $0.06 \mathrm{~mm}(4 \phi)$ mesh screens to obtain their percent by weight of gravel, sand, and mud, and classified using the textural scheme of Folk (1968). Grain-size statistics for 25 samples representative of different textural classes were calculated by computer (Kamp 1979), after sieving of the sand and gravel fractions at $\frac{1}{2} \phi$ intervals and hydrophotometer analysis (Jordan et al. 1971) of the silt fraction at $\frac{1}{2} \phi$ intervals and of the total clay fraction $(<0.004 \mathrm{~mm} ; 8 \phi)$. Statistics determined included the first percentile (C $\phi)$ and median (Md $\phi)$ of Passega (1964), and the mean (Mz $\phi)$, sorting $\left(\sigma_{\mathrm{I}} \phi\right)$, skewness $\left(\mathrm{Sk}_{\mathrm{t}}\right)$, and kurtosis $\left(\mathrm{K}_{\mathrm{G}}\right)$ values of Folk \& Ward (1957). Tabulated results of textural, $\mathrm{pH}$, and $\mathrm{Eh}$ values are available from the author.

Bulk sediment composition was determined by $\mathrm{X}$ ray diffraction analyses, by microscopic observation of the light and heavy mineralogy of sand fractions after sedimentation through tetrabromoethane (s.g. 2.94 ), and by examination of scanning electron images of the less than $2 \mu \mathrm{m}, 2-16 \mu \mathrm{m}$, and 16-63 $\mu \mathrm{m}$ centrifuged separates prepared using Lister's (1978) technique.

\section{RESULTS AND DISCUSSION}

\section{Morphology and geology}

Morphometric and other data for Lake Rotoma and its catchment are given in Table 1. The lake comprises 3 main basins: North Basin (max. depth $83 \mathrm{~m})$, South Basin (73.5 m), and Matutu Basin (38 m) (Fig. 1). The basins possibly formed as explosion craters and are separated by sediment-veneered bed-rock sills (Grange 1937). Their original shapes have been modified by extrusion of rhyolite flows on the west side of the lake and by spit and bar development along parts of the shoreline. Tephra thicknesses suggest that the Matutu Basin formed during eruption of Rotoma Ash, about 7300 years ago (Healy 1975). South Basin contains a prominent central submerged pinnacle, the Otangiwai Bank, formed by a steep-sided rhyolite plug. In preEuropean time this bank was an island with a village (Healy 1975), but now its summit lies beneath about $6 \mathrm{~m}$ of water. Similar, but smaller, submerged peaks are defined by the irregular form of depth contours elsewhere in South and North Basins (Irwin 1967).

Echo-sounding profiles, along with the detailed shore-normal transects measured by Clayton (1978), show that the depth of the shelf-slope break varies from $3 \mathrm{~m}$ to over $13 \mathrm{~m}$, with a lake-wide average of about $8 \mathrm{~m}$. Shelves bordering the more exposed eastern half of the lake (Fig. 1, wind-rose) extend into deeper water (commonly over $8 \mathrm{~m}$ and locally to about $20 \mathrm{~m}$ ), are wider (often exceed $100 \mathrm{~m}$ ), and have a more gentle gradient (less than 1 in 10) than their counterparts along the western shoreline (Fig. 3 ). The depth of the slope-basin break is $50-70 \mathrm{~m}$ in the main basins and, like the shelves, slopes are wider, of lower gradient, and extend deepest adjacent to shores facing the prevailing winds.

There are several lagoons, separated from the lake by vegetated bars of mixed sand and gravel (Fig. 1). The bars are 50-200 $\mathrm{m}$ wide, and show a series of beach ridges parallel to the shoreline, built up by storms during higher lake levels. The bar forming the Otumarokura Lagoon in Matutu Basin was largely submerged and being eroded, with an

Table 1 Morphometric and hydrologic data for Lake Rotoma (adapted mainly from McColl $(1972,1975)$, Jolly \& Irwin (1975), and Clayton (1978)). The maximum depth and the secchi disc depth in parentheses are those measured in this survey.

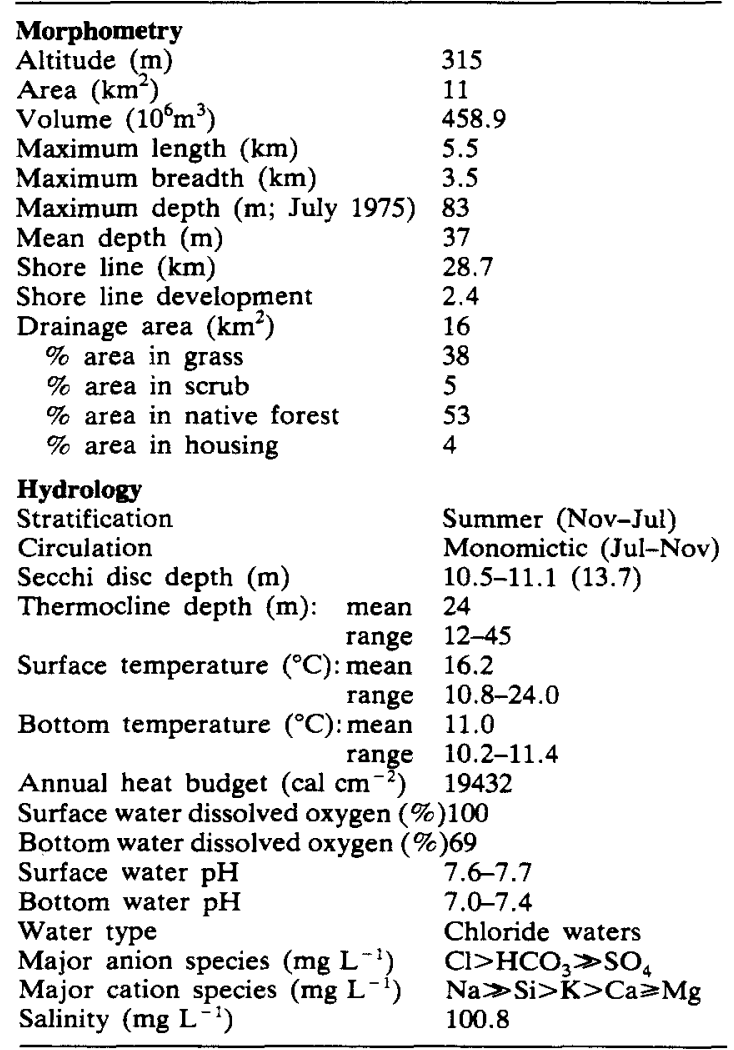




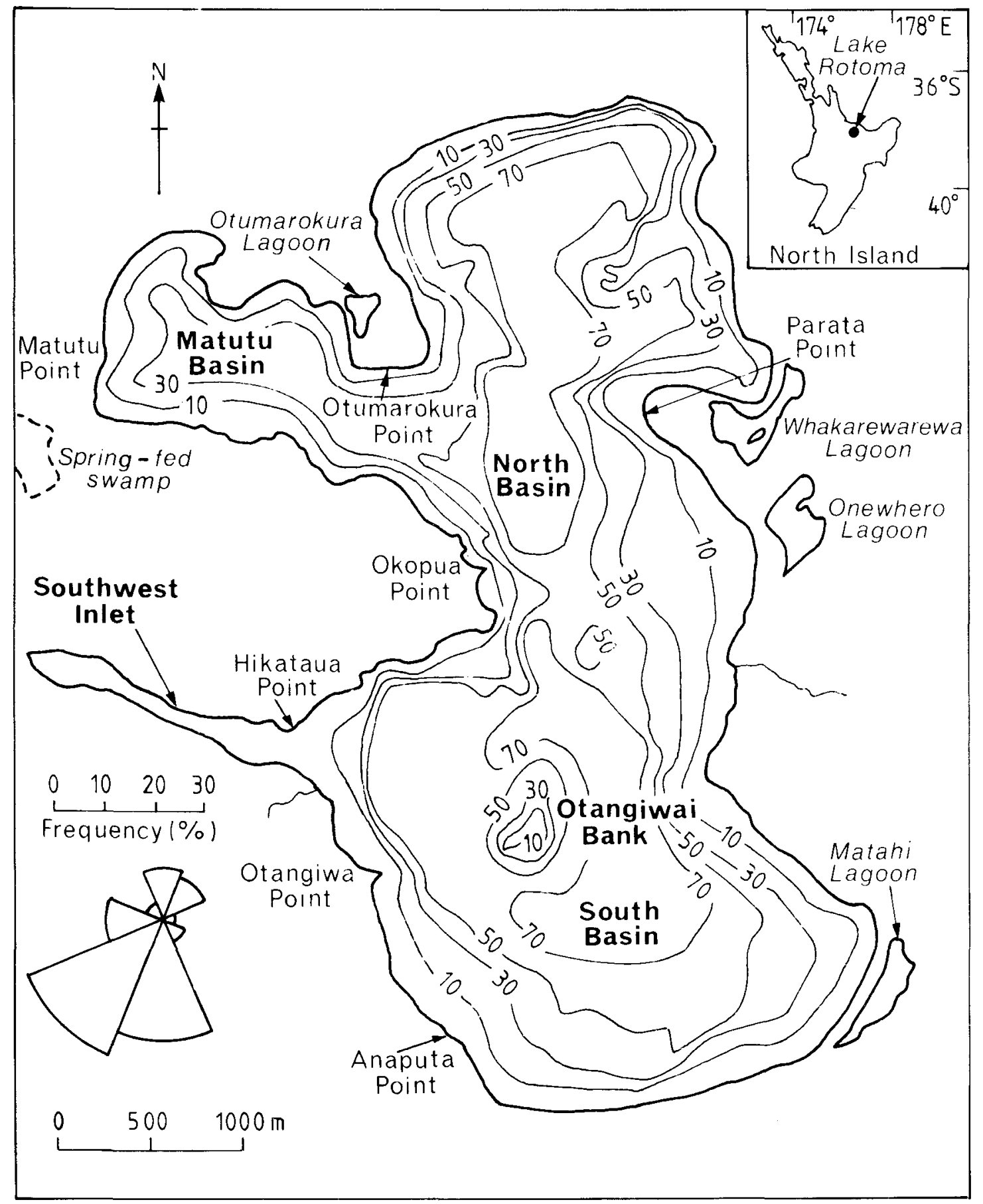

Fig. 1 Locality map for Lake Rotoma showing generalised bathymetry ( $\mathrm{m}$; after Irwin (1967)) and wind-rose for nearby Rotoehu Forest (N.Z. Meteorological Service 1975-77). 


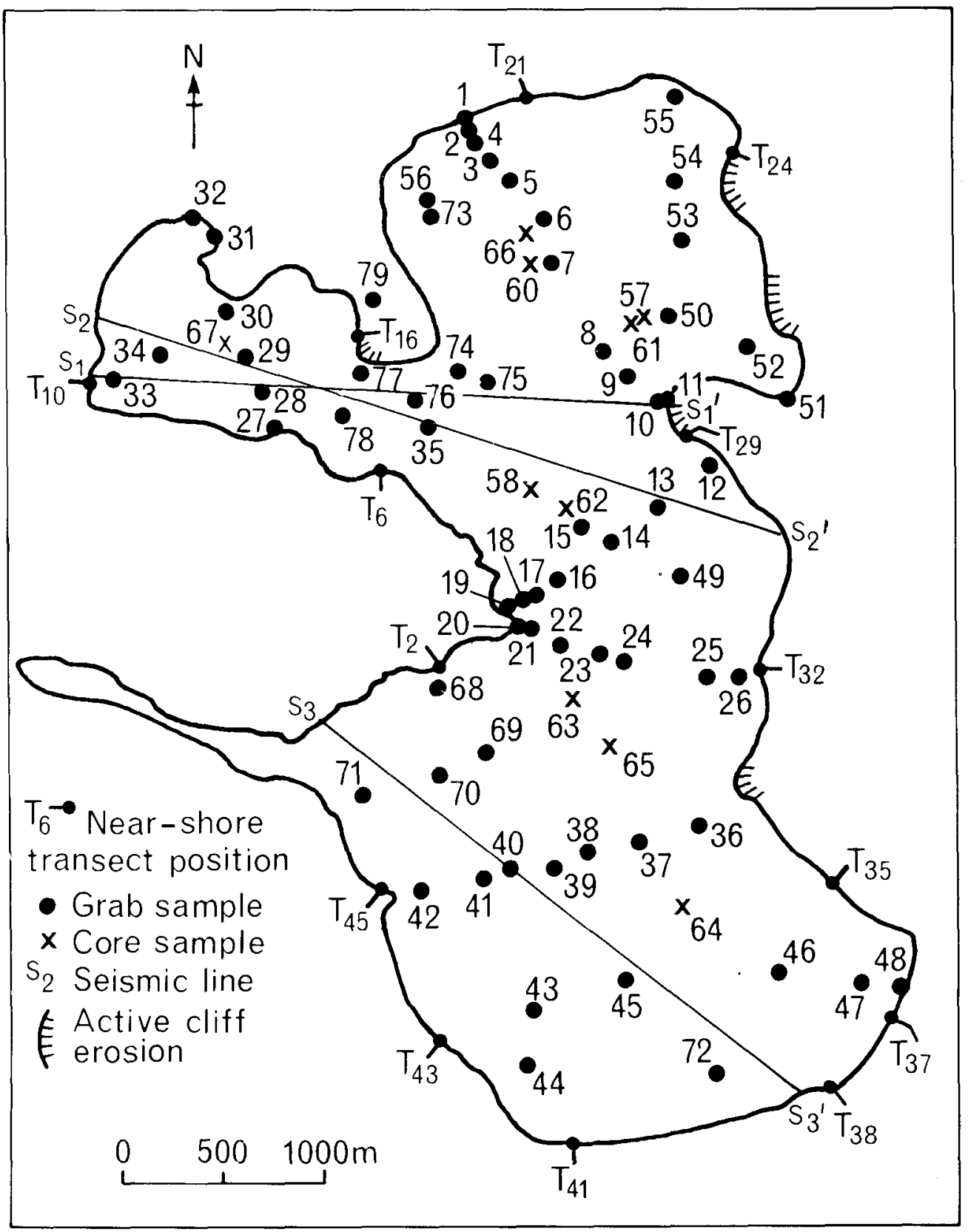

Fig. 2 Sample sites, nearshore morphologic transect positions, seismic lines, and actively eroding cliffline locations in Lake Rotoma. 

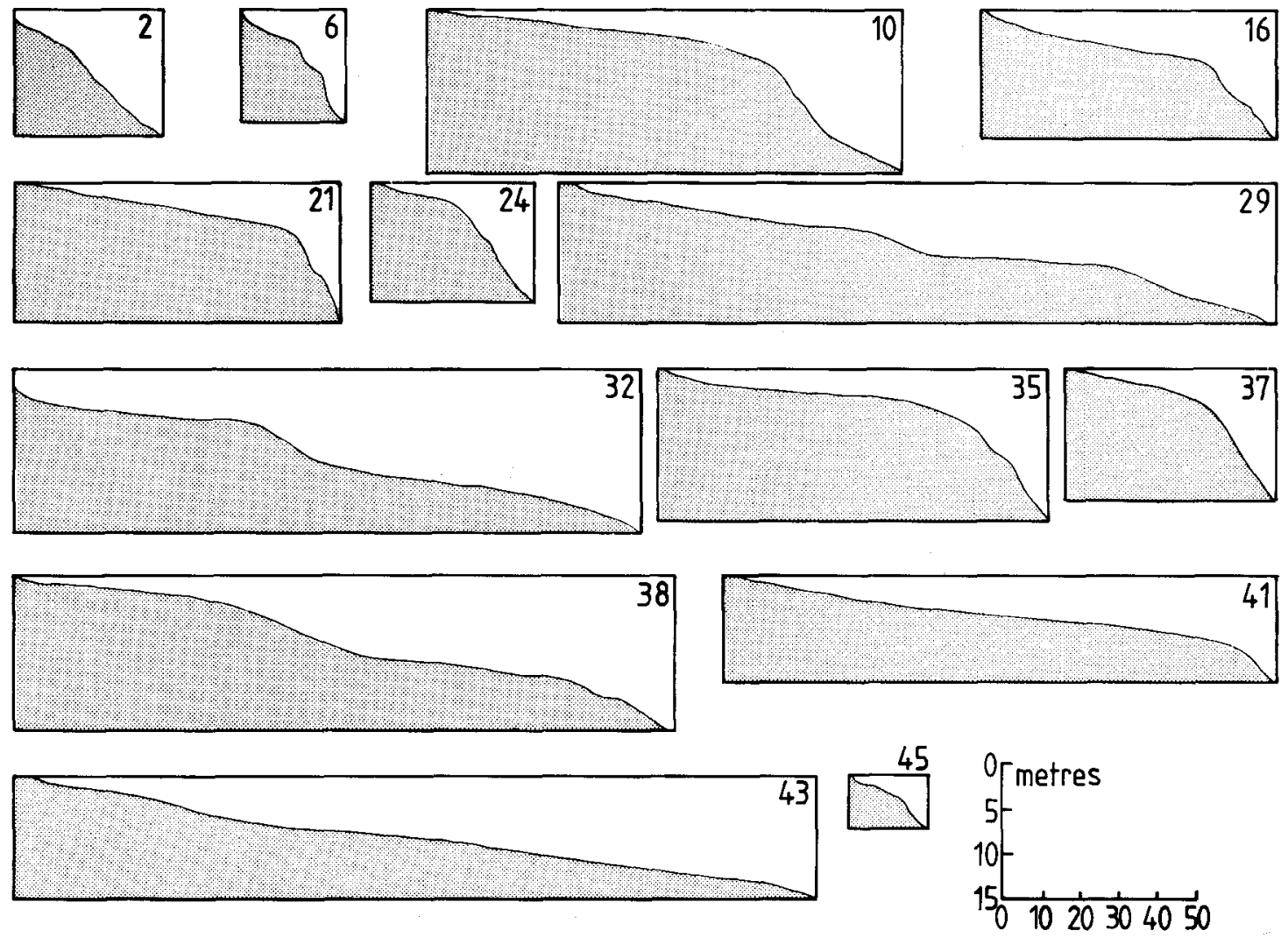

Fig. 3 Nearshore bottom profiles (see Fig. 2) for Lake Rotoma (after Clayton 1978). Vertical exaggeration $\times 2$.

exposed sand spit on its southern end only. All the major lagoons are on exposed west-facing shores between rocky headlands. One explanation for their development is longshore drift set up by wave refraction in littoral waters between promontories.

Catchment geology south and west of the lake is mainly glassy rhyolite flows of the Haparangi Rhyolite, while to the north and east are extensive deposits of poorly compacted white pumice breccias of 41 000-year-old Rotoiti Breccia (Healy et al. 1964). Thin pumice flow breccias and tephras of the 30 100-year-old Mangaoni Lapilli Formation crop out locally in the catchment (Howorth 1975), and thicker deposits $(4-6 \mathrm{~m})$ of friable Holocene tephras, dominated by Rotoma Ash $(7330 \pm 235$ years B.P.), occur widely on the steep slopes about the lake (Vucetich \& Pullar 1964). Recent catchment soils are developed mainly on the freedraining Tarawera Ash and Lapilli, basaltic tephra erupted from Mt Tarawera to the south in A.D. 1886.

\section{Lake waters}

The 2 small surface streams which enter Lake Rotoma both often dry up in summer (Gee 1960). Small inflows from hot springs are known, especially in the north-eastern corner of the lake (McColl 1975). There is no natural surface outflow from the lake, but subsurface drainage through the porous Rotoiti Breccia in the south-western wall of Matutu Basin maintains a small spring-fed swamp (Fig. 1) which drains westwards into adjacent Lake Rotoehu. About half the potential runoff from Rotoma catchment is lost by subsurface seepage to adjoining catchments (Anon. 1972).

From 1911 to 1971 the water level in Lake Rotoma fluctuated markedly about an overall rising trend of at least $6 \mathrm{~m}$ (R. J. Pittams, unpublished data). Between 1972 and the survey period (1975) the level dropped below the 1971 maximum by about $2 \mathrm{~m}$. The short-term fluctuations closely parallel variations in annual rainfall (Clayton 1978), and the longer-term rise in lake level may be 
controlled by secular variations in precipitation ( $R$. J. Pittams, unpublished data) or be related partly to progressive clogging of natural subsurface outlets by fine sediments (Howard 1971; McColl 1972). Sudden changes in lake level have also occurred following major earth movements such as the 1931 Napier earthquake, when the submerged Otangiwai Bank in South Basin was temporarily exposed as an island (Clayton 1978). Since 1975 the maximum level of Lake Rotoma has been controlled at an altitude of $315.8 \mathrm{~m}$, about $2 \mathrm{~m}$ below the highest level reached in 1971 , by excavation of a canal between the western end of the Southwest Inlet and Lake Rotoehu.

Physico-chemical properties for Lake Rotoma are summarised from McColl $(1972,1975)$ and Jolly \& Irwin (1975) in Table 1. The lake is warm monomictic; thermal stratification begins in early summer, and is destroyed by overturn and mixing of waters in late winter. The waters were stratified with a pronounced thermocline at $30-35 \mathrm{~m}$ depth in July 1975 (Fig. 4). Secchi depths ranged from 10.7 to 13.7 m (Fig. 4) and were mainly closer to the latter depth, which extends the previously reported secchi depth range from Lake Rotoma (Table 1).

Waves and long-shore currents are produced by winds blowing mainly from south to west and, less commonly, from the north (Fig. 1, wind-rose). Winds are slightly stronger (about $7 \mathrm{~km} \mathrm{~h}^{-1}$ ) in late autumn to early summer, but for a few days every month attain average speeds in excess of $15 \mathrm{~km} \mathrm{~h}^{-1}$ and, in winter months, often reach average daily speeds of $25-30 \mathrm{~km} \mathrm{~h}^{-1}$ (N.Z. Meterological Service 1975-1977). During the survey period waves moved mainly eastward under the influence of westerly winds. Over one 12-hour storm period a significant wave height of up to $0.5 \mathrm{~m}$ was visually estimated in open water in South Basin. Oscillation ripples formed in sediments down to depths of $\sim 2.5 \mathrm{~m}$ and it is inferred from this, as well as independent SCUBA records of bottom characteristics (Clayton 1978; A. A. Devcich, pers. comm. 1980), that effective storm wave base is everywhere shallower than 3-5 $\mathrm{m}$.

\section{Sediment texture}

Surficial bottom sediments range widely in texture (Fig. 5) from sandy gravels to muds (the latter are more specifically silts; see Fig. 5B and caption). The sediments generally fine with increasing water depth (Fig. 6), and 3 major textural groups, namely mixed sand-gravel, mixed sand-mud, and mud, form roughly shore-parallel sediment belts coincident roughly with 4 environments: beach, shelf, slope, and basin (Fig. 7). Beach deposits range from pure sands to gravels, but are predominantly gravelly

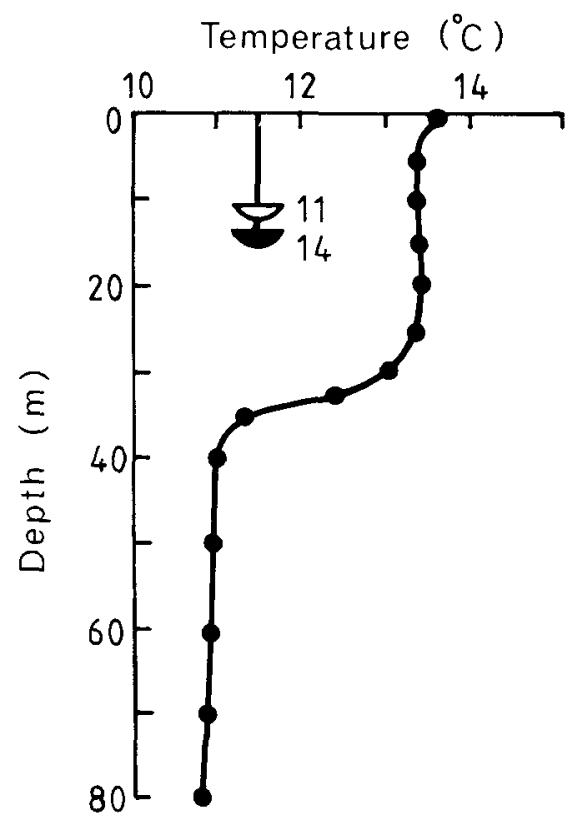

Fig. 4 Temperature profile and secchi depths (m) at Stn 58, Lake Rotoma, 7 July 1975.

sands and sandy gravels (Facies 1 ). Shelf deposits to $20 \mathrm{~m}$ depth consist mainly of slightly gravelly and gravelly sands (Facies 2a) that are commonly interrupted by a nearshore mud belt (Facies 2b) associated with rooted aquatic vegetation in water depths less than $12 \mathrm{~m}$. The plant-associated mud covers the whole of Southwest Inlet. Slope deposits are muddy sands (Facies 3a) and sandy muds (Facies $3 b$ ), locally gravelly, which grade into pure muds (Facies 4) of the flat-floored North, South, and Matutu Basins. Muds extend across the sill separating North and South Basins but do not fully cover the sill between North and Matutu Basins. Basinal muds occur in considerably shallower waters $(30-40 \mathrm{~m})$ in Matutu Basin than they do elsewhere in the lake.

Grain-size parameters averaged for representative samples from the environmentally-related sediment textural facies (Fig. 7) are given in Table 2. Note especially that average size (Mzh and $\mathrm{Md} \phi)$ decreases systematically from very coarse sand at the shoreline to fine silt in the basins (e.g., Fig. 8); dominant size modes occur in the coarse to medium sand grade in sandy sediments, and in the fine to very fine silt grade in mud-dominated deposits; the coarsest grains $(C \phi)$ in most sediments attain gravel size; and sorting $\left(\sigma_{\mathrm{I}} \sigma\right)$ of grains is generally poor and is due typically to an excess of coarse sizes in deposits, giving negative-skewness $\left(\mathbf{S k}_{\mathrm{I}}\right)$. 

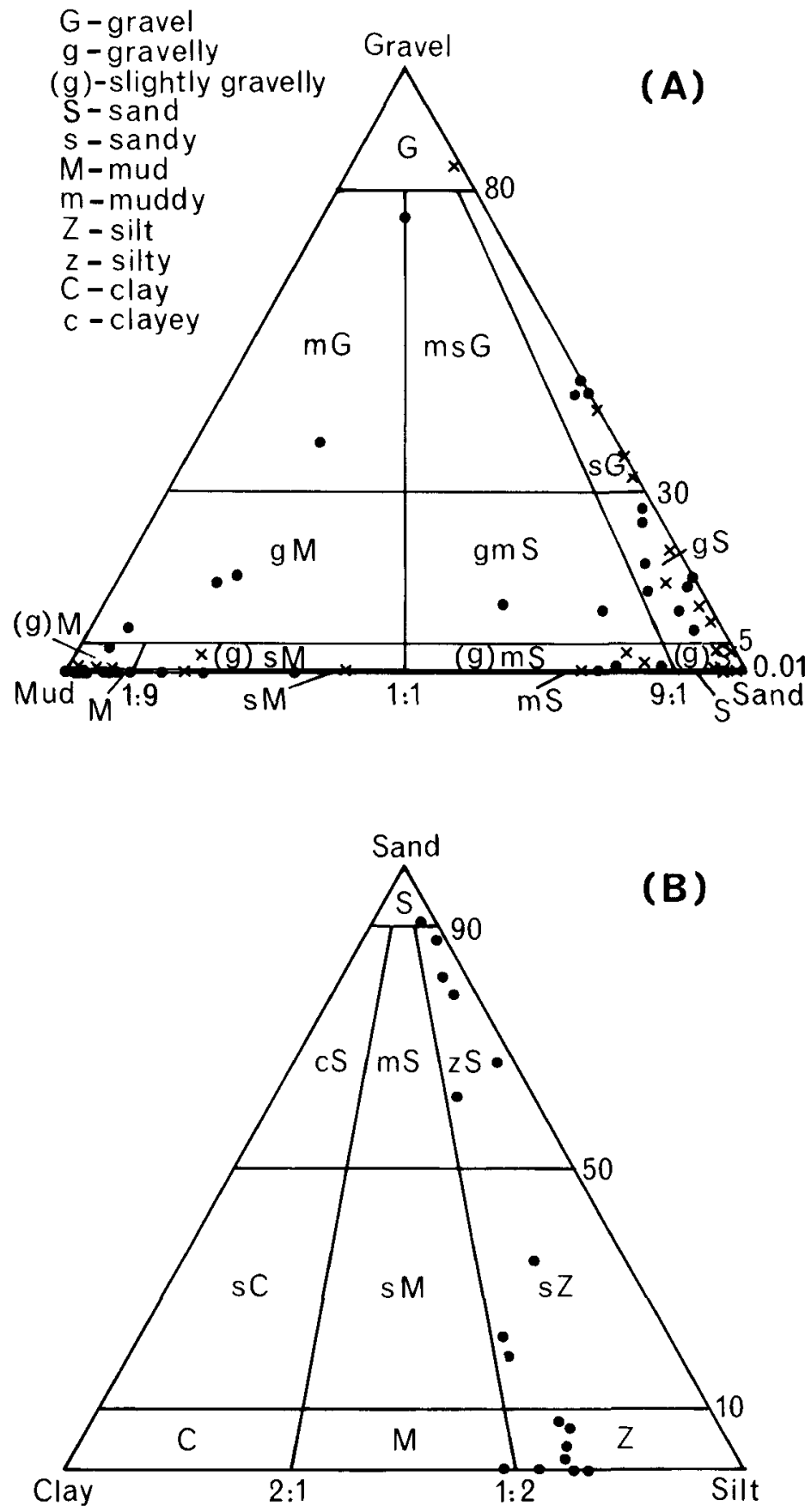

Fig. 5 Triangular textural plots (Folk 1968) of surficial bottom sediments in Lake Rotoma. Dots represent samples analysed in detail; crosses represent approximate texture of all other samples collected; gravel, $>2 \mathrm{~mm}(<-1 \phi)$; sand, $0.06-2 \mathrm{~mm}(4$ to $-1 \phi)$; mud, $<0.06 \mathrm{~mm}(>4 \phi)$; silt, $0.004-0.06 \mathrm{~mm}(8-4 \phi)$; clay, $<0.004 \mathrm{~mm}$ $(>8 \phi)$. Note especially that the term mud refers to a combination of silt and clay. Because the clay : silt ratio in samples (B) is typically less than $1: 2$, the names muddy and mud can be replaced by the more specific terms silty and silt respectively. 
Table 2 Bulk texture and grain size statistical parameters (after Folk \& Ward 1957; Passega 1964) averaged for sediments from each of the textural facies (Fig. 7) in Lake Rotoma. Abbreviations for bulk texture defined in Fig. 5. Abbreviations for grain size parameters are: Mz $\phi$ through $\mathrm{C} \phi-\mathrm{gr}$, gravel; vcs, very coarse sand; $c s$, coarse sand; ms, medium sand; vfs, very fine sand; $c z$, coarse silt; mz, medium silt; fz, fine silt; vfz, very fine silt; $\sigma_{\mathrm{I}} \phi-\mathrm{vps}$, very poorly sorted; ps, poorly sorted; ms, moderately sorted; $\mathbf{S k}_{\mathrm{I}}$-scs, strongly coarse-skewed; cs, coarse-skewed; ns, near-symmetrical; fs, fine-skewed; $\mathrm{K}_{\mathrm{G}}-\mathbf{l k}$, leptokurtic; mk, mesokurtic; pk, platykurtic.

\begin{tabular}{|c|c|c|c|c|c|c|}
\hline & \multicolumn{6}{|c|}{ Facies } \\
\hline & 1 & $2 a$ & $2 b$ & $3 a$ & $3 b$ & 4 \\
\hline \multicolumn{7}{|l|}{ Weight (\%) } \\
\hline Gravel & 37 & 22 & - & 5 & 2 & 5 \\
\hline Sand & 63 & 72 & 1 & 78 & 39 & 7 \\
\hline Mud & - & 3 & 99 & 17 & 59 & 88 \\
\hline Silt & - & 2 & 69 & 15 & 46 & 64 \\
\hline Clay & - & 1 & 30 & 2 & 13 & 24 \\
\hline Bulk texture & sG & gS & $\mathbf{M}$ & (g) $\mathrm{mS}$ & (g)sM & (g)M \\
\hline Mzф & $-0.4(\mathrm{ves})$ & $0.5(\mathrm{cs})$ & $6.5(\mathrm{fz})$ & $1.5(\mathrm{~ms})$ & $4.0(\mathrm{cz})$ & $5.3(\mathrm{mz})$ \\
\hline Mdф & $-0.4(v c s)$ & $0.7(\mathrm{cs})$ & $6.6(\mathrm{fz})$ & $1.4(\mathrm{~ms})$ & $4.0(\mathrm{cz})$ & $6.0(f z)$ \\
\hline Modal size & & & & & & \\
\hline $1^{\circ}$ & $\mathrm{cs}$ & $\mathrm{cs} / \mathrm{ms}$ & $\mathrm{fz}$ & ms & ms-fz & vfz \\
\hline $2^{\circ}$ & $\mathrm{gr}$ & gr & cz & $\mathrm{cz}$ & $\mathrm{cz}-\mathrm{mz}$ & $\mathrm{cz}$ \\
\hline$C \phi$ & $-3.3(g r)$ & $-3.4(\mathrm{gr})$ & $3.9(\mathrm{vfs})$ & $-2.0(\mathrm{gr})$ & $-1.7(\mathrm{gr})$ & $-3.0(\mathrm{gr})$ \\
\hline$\sigma_{I} \phi$ & $1.3(\mathrm{~ms})$ & $1.7(\mathrm{ps})$ & $1.0(\mathrm{~ms})$ & $2.0(\mathrm{vps})$ & $2.3(\mathrm{vps})$ & $1.7(\mathrm{ps})$ \\
\hline $\mathbf{S k}_{\mathrm{I}}$ & $+0.1(\mathrm{~ns})$ & $0.0(\mathrm{~ns})$ & $-0.2(\mathrm{cs})$ & $+0.2(\mathrm{fs})$ & $-0.1(\mathrm{cs})$ & -0.4 (scs) \\
\hline $\mathbf{K}_{\mathrm{G}}$ & $0.9(\mathrm{pk})$ & $1.5(\mathrm{lk})$ & $1.3(\mathrm{lk})$ & $1.5(\mathrm{lk})$ & $1.3(\mathrm{lk})$ & $1.0(\mathrm{mk})$ \\
\hline
\end{tabular}

\section{Sediment composition}

Organic matter in sediments usually constitutes less than $10 \%$ by weight, although in shelf muds associated with aquatic vegetation it may be as much as $20-40 \%$. In general, the finer sediments have more organic matter (Table 3 ).

Peroxide-digested samples contain various amounts of irregularly rounded volcanic rock fragments (predominantly pumice, glassy and stony rhyolite, and scoriaceous basalt), mainly little abraded, subhedral to euhedral grains of feldspar (dominantly plagioclase of both calcic oligoclase/sodic andesine and calcic andesine/sodic labradorite composition, with minor sanidine) and quartz (plagioclase feldspar: quartz ratio of sediments is high, ranging from $2: 1$ to $7: 1$ ), fresh crystals of opaque and ferromagnesian (heavy) minerals (opaques-magnetite and limonite, some ilmenite and leucoxene $\gg$ cummingtonite $\geqslant$ hypersthene $>$ calcic homblende $>$ augite $>$ biotite $\geqslant$ olivine), glass shards, biogenic opaline silica (principally diatoms, e.g., Melosira-dominant form-Cyclotella, Cocconeis, Anomoeoneis, Caloneis, Fragilaria, Navicula, Stauroneis, Surirella, Tabellaria, Gomophoneis, Rhopalodia, Eunotia, Epithemia, Pinnularia, Neidium, and Asterionella;
Table 3 Organic matter content of textural-environment sediment facies (see Fig. 7) in Lake Rotoma.

\begin{tabular}{lccc}
\hline Environment & Facies & $\begin{array}{c}\text { Organic matter (\% weight) } \\
\text { Mean }\end{array}$ & Range \\
\hline Beach & 1 & 0 & $0-0.2$ \\
Shelf & 2a & 0.1 & $0-0.3$ \\
& $2 \mathrm{~b}$ & 28.0 & $19.0-37.0$ \\
Slope & $3 \mathrm{a}$ & 1.8 & $0.4-4.4$ \\
& $3 \mathrm{~b}$ & 3.9 & $2.7-5.5$ \\
Basin & 4 & 4.9 & $2.6-9.0$ \\
\hline
\end{tabular}

rare sponge spicules), $\alpha$-cristobalite, and clay minerals (allophane $>$ halloysite/metahalloysite).

The relative abundance of these components is related to sediment texture (Fig. 9); the gravel fraction is completely dominated by rock fragments, the coarser sand grades by rock fragments and plagioclase feldspar, the finer sand grades by plagioclase, quartz, and, to a lesser extent, heavy minerals, and the mud fraction by diatomaceous silica, glass shards, $\alpha$-cristobalite, and clay minerals. Within the mud fraction (Fig. 10), glass shards and mineral fragments together dominate $(60-80 \%)$ the 


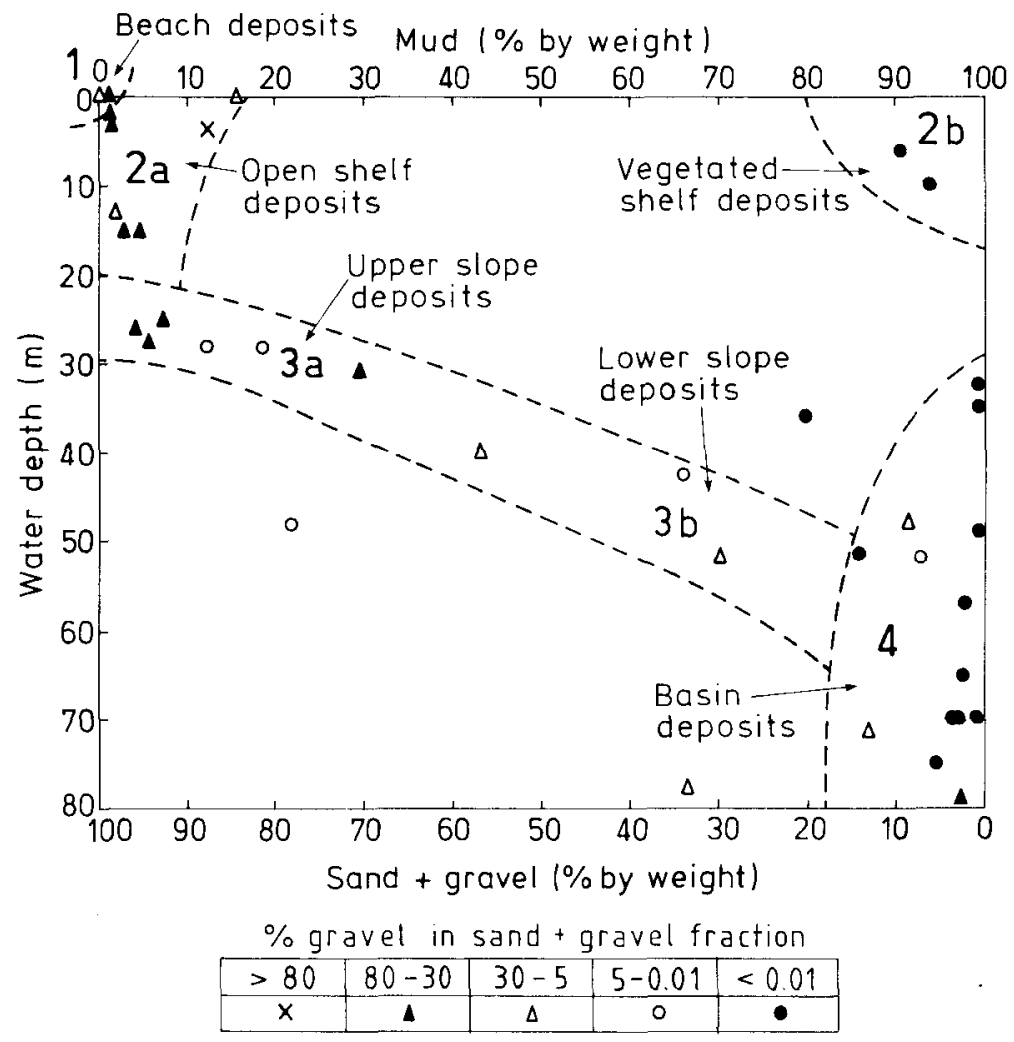

Fig. 6 Relationships between sediment texture and depth in Lake Rotoma. Numbers $1,2 a, \ldots 4$ refer to the sediment textural facies in Fig. 7; data point symbols indicate gravel content in combined sand plus gravel fraction of sediments, defined along base of figure.

medium and coarse silt grades $(6-4 \sigma)$, diatoms $(70$ $80 \%)$ the very fine and fine silt grades $(8-6 \sigma)$, and fluffy particulate aggregates of dominantly allophanic material $(50-80 \%)$ the clay fraction $(>8 \sigma)$, these components accounting for the observed size modes in the fine fraction of sediments (Table 2). Lake Taupo basinal muds show similar size-compositional partitioning (Lister 1978).

The composition of the terrigenous fraction of Rotoma sediments is consistent with derivation, directly and indirectly, from the lavas, ash-flow deposits, and air-fall tephras about the lake (Table 4).

\section{Bottom sediment $\mathbf{p H}$ and Eh}

Lake waters are aerobic, and their $\mathrm{pH}$ is about neutral (Table 1). During the survey period the $\mathrm{pH}$ and $E h$ of interstitial waters in surficial bottom sediments ranged from 6.5 to 8.0 and $+50 \mathrm{mV}$ to $+470 \mathrm{mV}$ respectively, the $\mathrm{pH}$ increasing and $\mathrm{Eh}$ decreasing as sampling depth increased (Fig. 11). These relationships probably reflect the fining of sediment texture with increasing water depth (Fig. 6). Finer sediments are less permeable and have higher organic contents (Table 3), with probably greater microbial activity producing lower Eh values. Under reducing conditions (Eh $<+150$ $\mathrm{mV}$ ) biochemical reactions such as the reduction of sulphate to sulphide, and the fixation of nitrogen by conversion to ammonia, will tend to increase the $\mathrm{pH}$ of sediment-pore waters (Stumm \& Baccini 1978), as occurs in the deeper Rotoma sediments.

\section{Short-core stratigraphy}

A portion of 1 of the 3 seismic profiles run in Lake Rotoma (Fig. 2) is reproduced in Fig. 12. While basinal areas are essentially flat-floored, the western slopes of the lake have a rough topography comprising several prominent, but generally small, dome-like structures. These features are typical of the very irregular tops and margins of rhyolite domes and coulees (e.g., Cole 1970b). The domes form the margins to a complex pattern of small depressions which have ponded a proportionately 


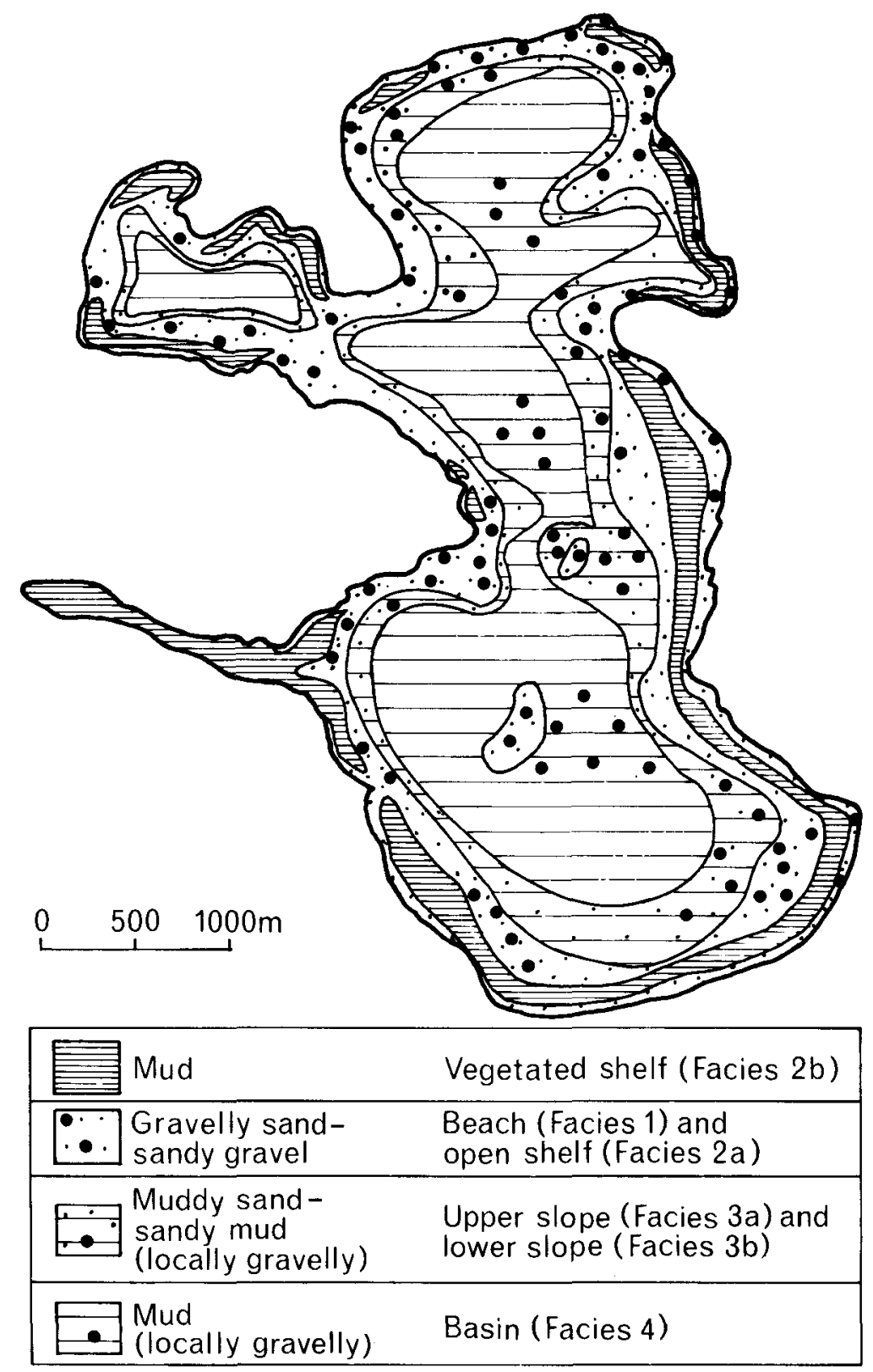

Fig. 7 Textural-environmental facies map for Lake Rotoma; large black dots indicate gravelly deposits.

increased thickness of sediment compared to the dome rims (Fig. 12). These mini-basins may form effective barriers to any basinwards transport of bottom sediments by turbidity currents or slumping. The exceptional steepness of the western and eastern margins to the deep central portion of North Basin is possibly suggestive of fault-control, and minor irregularities and discontinuities in subbottom reflectors at the foot of the slope indicate local sediment accumulation from slumping (Fig. 12).

The 11 short bottom cores from the basinal areas of Lake Rotoma comprise up to 6 major lithologic units, labelled I-VI (Fig. 13). Unit II represents the 
Table 4 Possible major sources of mineral components in surficial bottom sediments of Lake Rotoma. Abbreviations for sources are: Haparangi, Haparangi Rhyolite; Rotoiti, Rotoiti Breccia Formation; Mangaone, Mangaone Lapilli Formation; Rotoma, Rotoma Ash; Kaharoa, Kaharoa Ash; Tarawera, Tarawera Ash and Lapilli. Stratigraphic and/or compositional information from Grange (1937), Healy et al. (1964), Vucetich \& Pullar (1964), Ewart (1966), Cole (1970a,b), Howorth (1975), Lawless (1975), Kirkman (1976), Mitsui \& Taguchi (1977), and Kohn \& Glasby (1978), among others.

\begin{tabular}{|c|c|}
\hline Component & Major source materials \\
\hline \multicolumn{2}{|l|}{ Rock fragments } \\
\hline Pumice & $\begin{array}{l}\text { Rotoiti, Mangaone, } \\
\text { Kaharoa }\end{array}$ \\
\hline Rhyolite & Haparangi \\
\hline Scoriaceous basalt & Tarawera \\
\hline \multicolumn{2}{|l|}{ Feldspar } \\
\hline Sodic plagioclase & Haparangi \\
\hline Soda-lime plagioclase & Late Quaternary tephras \\
\hline Lime plagioclase & Tarawera \\
\hline Sanidine & Haparangi \\
\hline \multicolumn{2}{|l|}{ Silica } \\
\hline Quartz & $\begin{array}{l}\text { Haparangi, Late } \\
\text { Quaternary tephras }\end{array}$ \\
\hline Glass shards & Late Quaternary tephras \\
\hline Opaline silica & $\begin{array}{l}\text { Intralake diatom } \\
\text { frustules }\end{array}$ \\
\hline Cristobalite & $\begin{array}{l}\text { Haparangi, alteration of } \\
\text { amorphous silica }\end{array}$ \\
\hline \multicolumn{2}{|l|}{ Heavy minerals } \\
\hline Magnetite & Late Quaternary tephras \\
\hline Cummingtonite & Rotoiti, Rotoma \\
\hline Hypersthene & $\begin{array}{l}\text { Rotoiti, Mangaone, } \\
\text { Rotoma, Kaharoa }\end{array}$ \\
\hline Calcic-hornblende & Rotoma \\
\hline Augite & Kaharoa \\
\hline Biotite & Kaharoa \\
\hline Olivine & Tarawera \\
\hline \multicolumn{2}{|l|}{ Clay Minerals } \\
\hline Allophane & Holocene tephras \\
\hline Halloysite & Lake Pleistocene tephras \\
\hline
\end{tabular}

air-fall ejecta of the A.D. 1886 Tarawera Ash and Lapilli eruption from nearby Mt Tarawera (Grange 1937; Cole 1970a). The stratigraphic position, highly pumiceous nature, and abundance (up to $95 \%$ ) of biotite in the heavy mineral fraction of units IV-VI indicate that they are air-fall and/or reworked ejecta from the A.D. 1020 Kaharoa Ash eruption from Mt Tarawera (Cole 1970a). Textural variations between units IV-VI may relate to different eruptive pulses or to significant changes in wind directions during the Kaharoa eruption (Grange 1937).

Rough estimates of rates of sedimentation of basinal diatomaceous muds in Lake Rotoma are given in Table 5 . The suggested increase in depositional rates since the Tarawera eruption (A.D. 1886), also reported for sediments from Lake

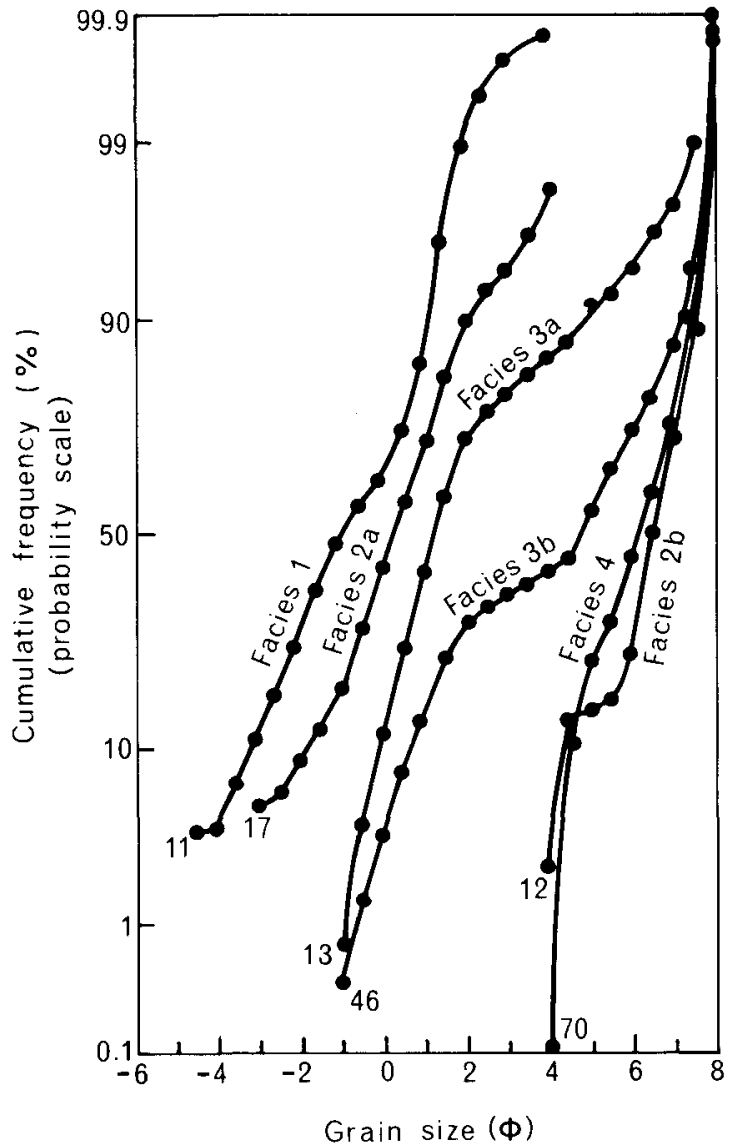

Fig. 8 Grain-size distribution curves representative of each of the major textural-environmental sediment facies (Fig. 7) in Lake Rotoma. Note the progressive fining of texture from Facies 1 to 4 , and that the curve characteristics for slope deposits (Facies $3 \mathrm{a}$ and $3 \mathrm{~b}$ ) can be derived simply by mixing of sediments from the shallower shelf (Facies 2a) and deeper basinal (Facies 4) facies. The truncation sizes between log-normal segments of the curves near $2 \phi(0.25 \mathrm{~mm})$ and $4 \phi(0.06 \mathrm{~mm})$ may approximate the maximum sizes capable of being moved as saltation and suspension load respectively in Lake Rotoma (cf. Visher 1969).

Rotorua (Fish 1979), implies an increase in the fertility level of waters and may be related to farm development in the catchment (e.g., Cassie 1978).

\section{Sedimentation}

The supply of terrigenous clastics to Lake Rotoma is at present minimal, as only 2 tiny ephemeral streams drain into the lake and the catchment is mainly under native forest and scrub growing on exceptionally free-draining tephric soils, which limits any important contribution from direct surface run-off. 
Table 5 Sedimentation rates of diatomaceous muds in basinal areas of Lake Rotoma calculated simply from measuring the thicknesses of degasified and dewatered, compacted core sediments (Fig. 13) and knowing the ages of the bounding tephras. Unfortunately the core intervals were not weighed, which would have enabled a more accurate estimate of depositional rate in terms of dry weight $\left(\mathrm{g} \mathrm{cm}^{-2} \mathrm{a}^{-1}\right.$, cf. Fish 1979), but the approximate doubling of sedimentation rates since the Tarawera eruption is probably of the right general order.

\begin{tabular}{|c|c|c|c|c|c|c|}
\hline \multirow[b]{2}{*}{ Unit } & \multirow[b]{2}{*}{ Lithology } & \multicolumn{2}{|c|}{$\begin{array}{l}\text { Thickness } \\
\text { (cm) }\end{array}$} & \multirow{2}{*}{$\begin{array}{l}\text { Date } \\
\text { (A.D.) }\end{array}$} & \multicolumn{2}{|c|}{$\begin{array}{l}\text { Sedimentation } \\
\text { rate }\left(\mathrm{mm} \mathrm{a}^{-1}\right)\end{array}$} \\
\hline & & Average & Range & & Average & Range \\
\hline : & & & & 1975 & & \\
\hline I & Diatomaceous mud & 6 & $3-15$ & & 0.7 & $0.3-1.7$ \\
\hline II & Tarawera tephra & 10 & $5-15$ & 1886 & & \\
\hline & Diatomaceous mud & 30 & $20-50$ & & 0.3 & $0.2-0.6$ \\
\hline IV-VI & Kaharoa tephra & 50 & $40-90$ & 1020 & & \\
\hline
\end{tabular}

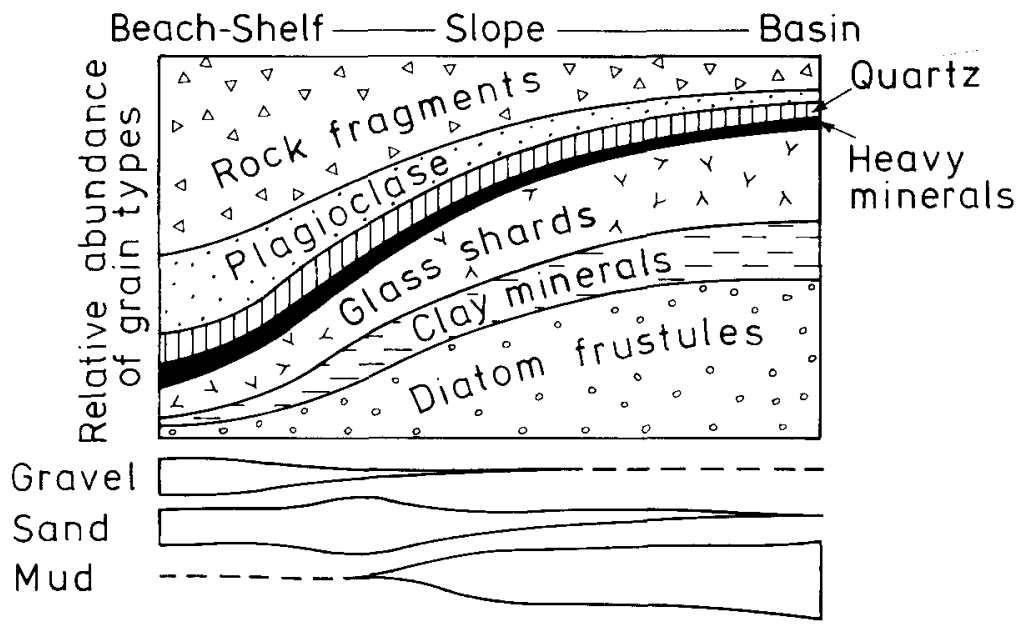

Fig. 9 Generalised relationships between composition, texture, and environment of bottom sediments in Lake Rotoma.

Fig. 10 (opposite) Scanning electron microscope images of the fine fractions of selected Lake Rotoma sediments. A, coarser silt fraction $(6-4 \phi)$ of Sample 45 , showing preponderance of mineral fragments and glass shards with scattered diatoms (including Melosira, Eunotia, Fragilaria, Cyclotella, and Rhopalodia); B, coarser silt fraction (6-4\$) of Sample 73, dominated by glass shards and rare diatoms (including Epithermia); C, finer silt fraction (8-6 $\phi$ ) of Sample 44, containing abundant diatoms, dominated by Melosira, but including Fragilaria, Pinnularia, Cyclotella, and Navicula; D, finer silt fraction (8-6申) of Sample 45 (cf. A), showing preponderance of diatoms (including Melosira, Navicula, Surirella, Pinnularia, Cyclotella, Neidium, and Eunotia); E, finer silt $(8-6 \phi)$ and clay $(>8 \phi)$ fraction of Sample 12, including whole and fragmented diatom frustules (mainly Melosira) and common fluffy aggregates of glass and ? allophane; $\mathrm{F}$, clay fraction $(>8 \phi)$ of Sample 73 showing fluffy aggregates of probable allophanic material. (Bar scale length $20 \mu \mathrm{m}$ in $\mathrm{A}, \mathrm{C}$, and $\mathrm{D}, 10 \mu \mathrm{m}$ in $\mathrm{B}$ and $\mathrm{E}$, and $1 \mu \mathrm{m}$ in $\mathrm{F}$ ). 


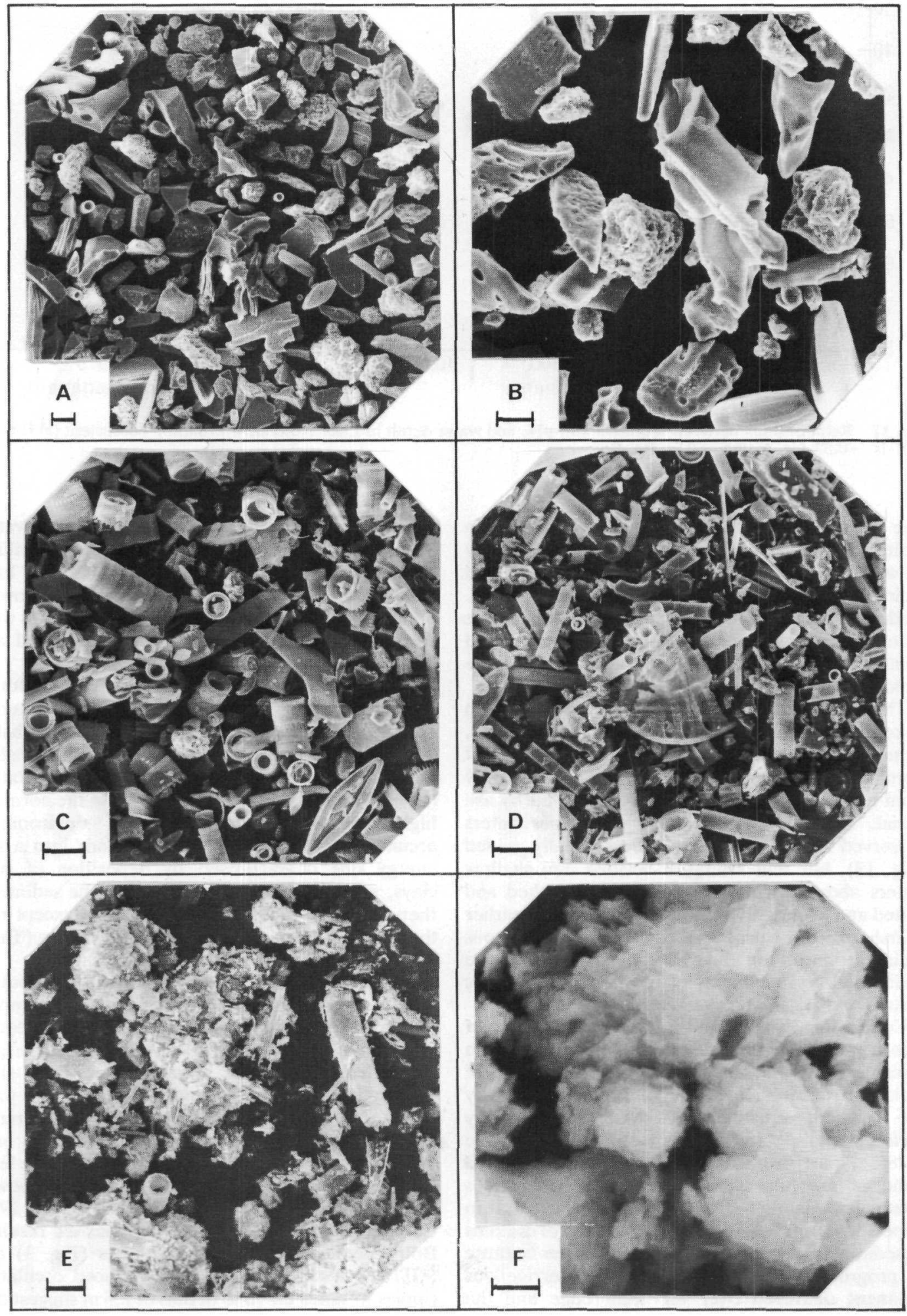



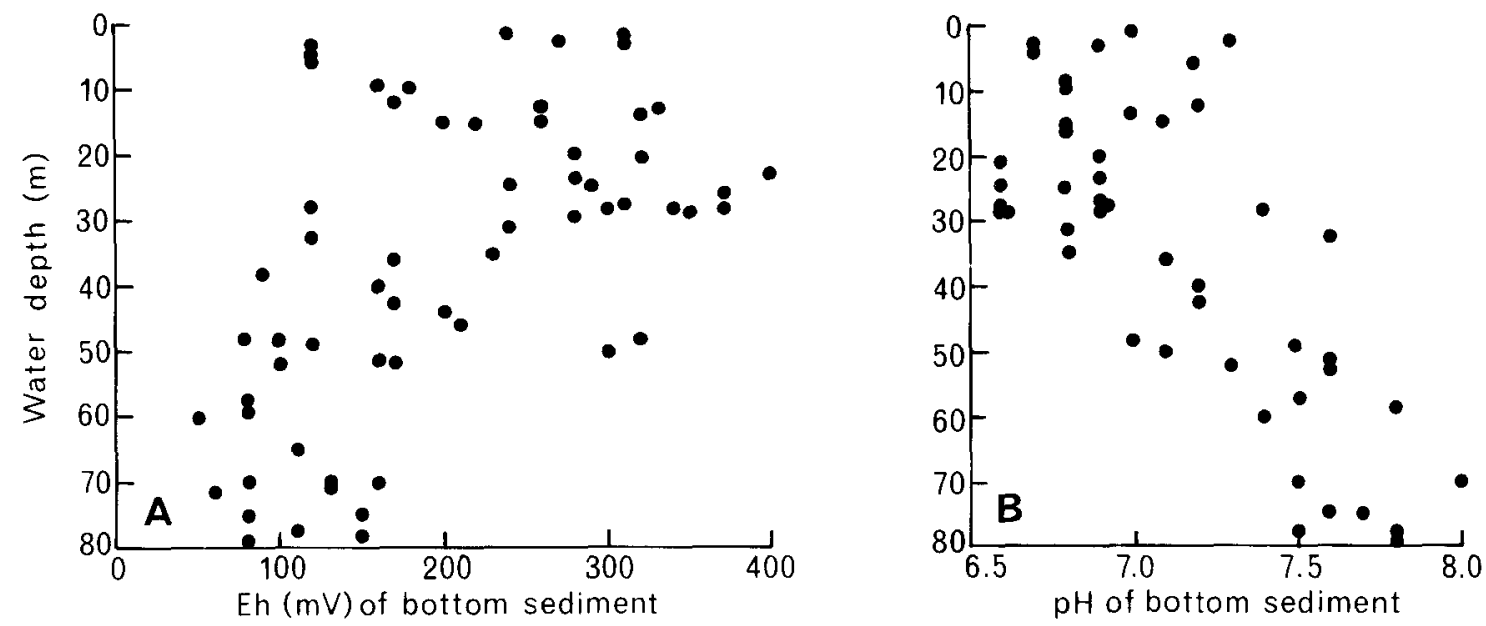

Fig. 11 Relationships between sediment $\mathrm{Eh}, \mathrm{pH}$, and water depth in Lake Rotoma; correlation coefficient $(r)$ for $P=$ 0.01 is -0.53 for $\mathrm{A}$ and +0.74 for $\mathrm{B}$.

The main source of small quantities of modern sediment is from local cliff-line erosion, especially on west-facing promontories of Rotoiti Breccia and their capping mantle of younger tephras (Fig. 2). Undercutting by wave action and ultimate collapse of cliff faces has been accelerated by the rapid fluctuations and overall rise of water level in Lake Rotoma in historical times (Howard 1971).

The great bulk of the terrigenous sediment in Lake Rotoma has been'supplied by volcanic ejecta, either falling directly into the lake or washed into it from the catchment soon after falling, especially from areas where vegetation was destroyed by ash burial. Tephric material settling in deeper waters preserved its identity and may be normally graded (Fig. 13), but that falling or washed into shallow waters above storm wave base was reworked and sorted and eventually thoroughly mixed with earlier nearshore sediments. Rapid transport of terrigenous sediment into the lake is supported by the unabraded crystal shapes of most felsic and mafic grains, and by their unweathered condition.

Contrasting with the infrequent periods of accelerated lake sedimentation associated with volcanic activity has been the slow, steady rain of biological detritus, overwhelmingly dominated by the siliceous frustules of diatoms, especially Melosira and Cyclotella (Flint 1975, 1977; Cassie 1978). Apart from entrapment within localised stands of nearshore aquatic vegetation, the frustules accumulate mainly well below effective wave base in slope and basinal sediments. The content of diatoms in sediments increases with depth of water because of progressively less dilution by fine terrigenous sediment delivered over the shelf edge and the greater deposition of diatoms in deeper water. Scattered basaltic (and rarely pumiceous) lapilli in the surficial diatomaceous muds (Fig. 7) have probably been reworked from below by burrowing organisms (Davis 1974; Main 1976), or perhaps were floating fragments that became water-logged and sank.

A wide variety of aquatic macrophytes are found in the nearshore regions of Lake Rotoma (Clayton 1978). These plants bind the substrate, baffle currents, and trap sediment. By lateral spreading they produce coalescing tracts of dense vegetation (Chapman et al. 1971) which transform the normally high energy nearshore lake-bed environment accumulating sands and gravelly sands into a low energy one characterised by deposition of silts, clays, and diatom frustules (Fig. 7). The sediments then resemble those in the lake basins except that they contain plant remains and more humus (Table 3).

The superficially simple sediment distribution patterns in Lake Rotoma belie a rather complex history of deposition involving a variety of processes and sources of both biological and physical origin. The offshore fining of sediment across the shelf expected from the shore-normal sorting by wave action (Pickrill 1978) is complicated by the variable development of tracts of aquatic vegetation and, more importantly, by past fluctuations in lake level which, over the 60-year period up to 1972 showed relative changes of at least 6-10 m (Howard 1971; Clayton 1978; R. J. Pittams, unpublished results). Both the nearshore bottom profiles (Fig. 3) and SCUBA observations of wave-induced oscillation ripples in sands down to depths of $2.5 \mathrm{~m}$ suggest that 


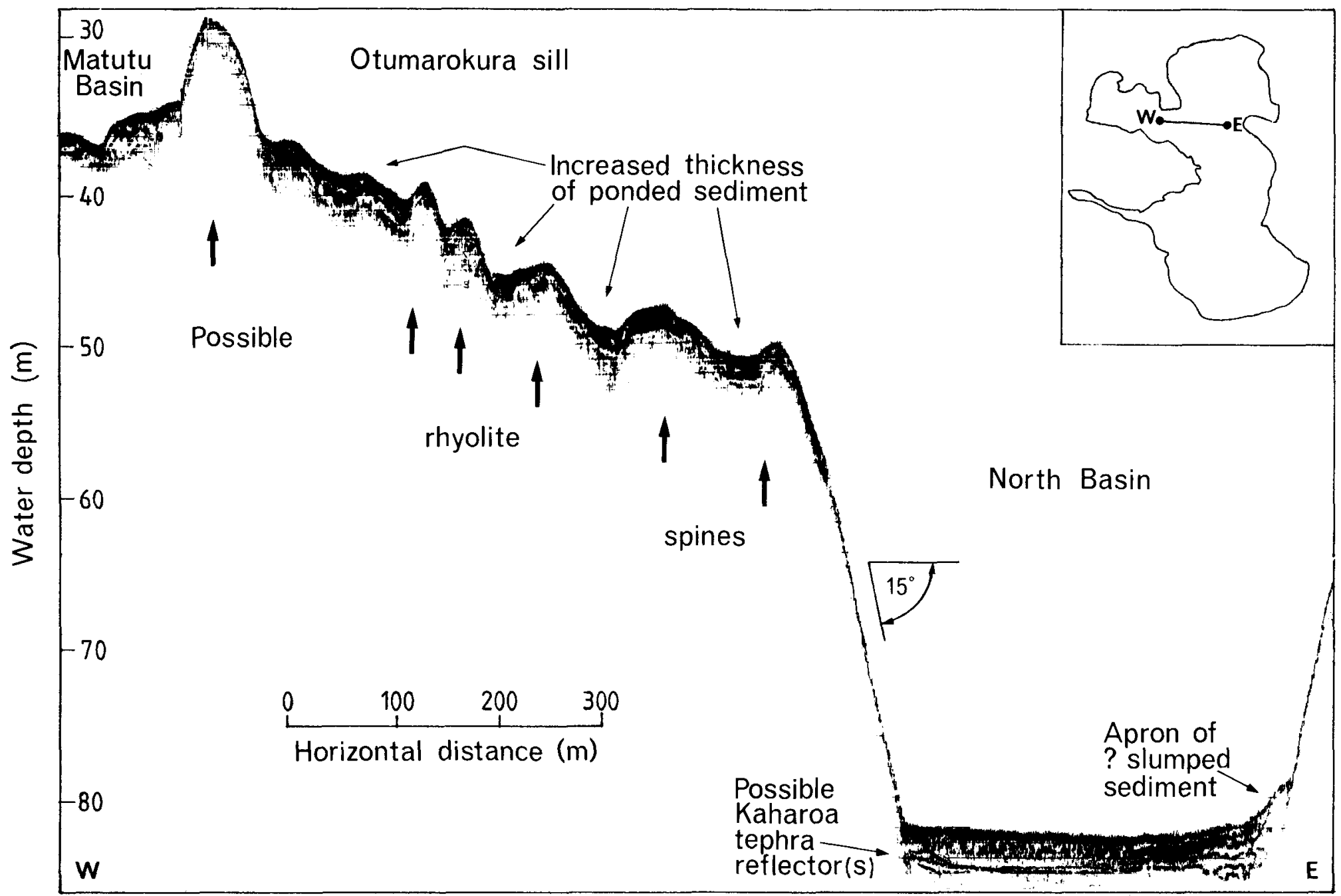

Fig. 12 Bottom and shallow sub-bottom structures along a portion of Seismic Line 1 (S1 in Fig. 2) from Matutu Basin to North Basin, Lake Rotoma. Sub-bottom reflectors in North Basin have been emphasised. Vertical exaggeration $\times 15$. 


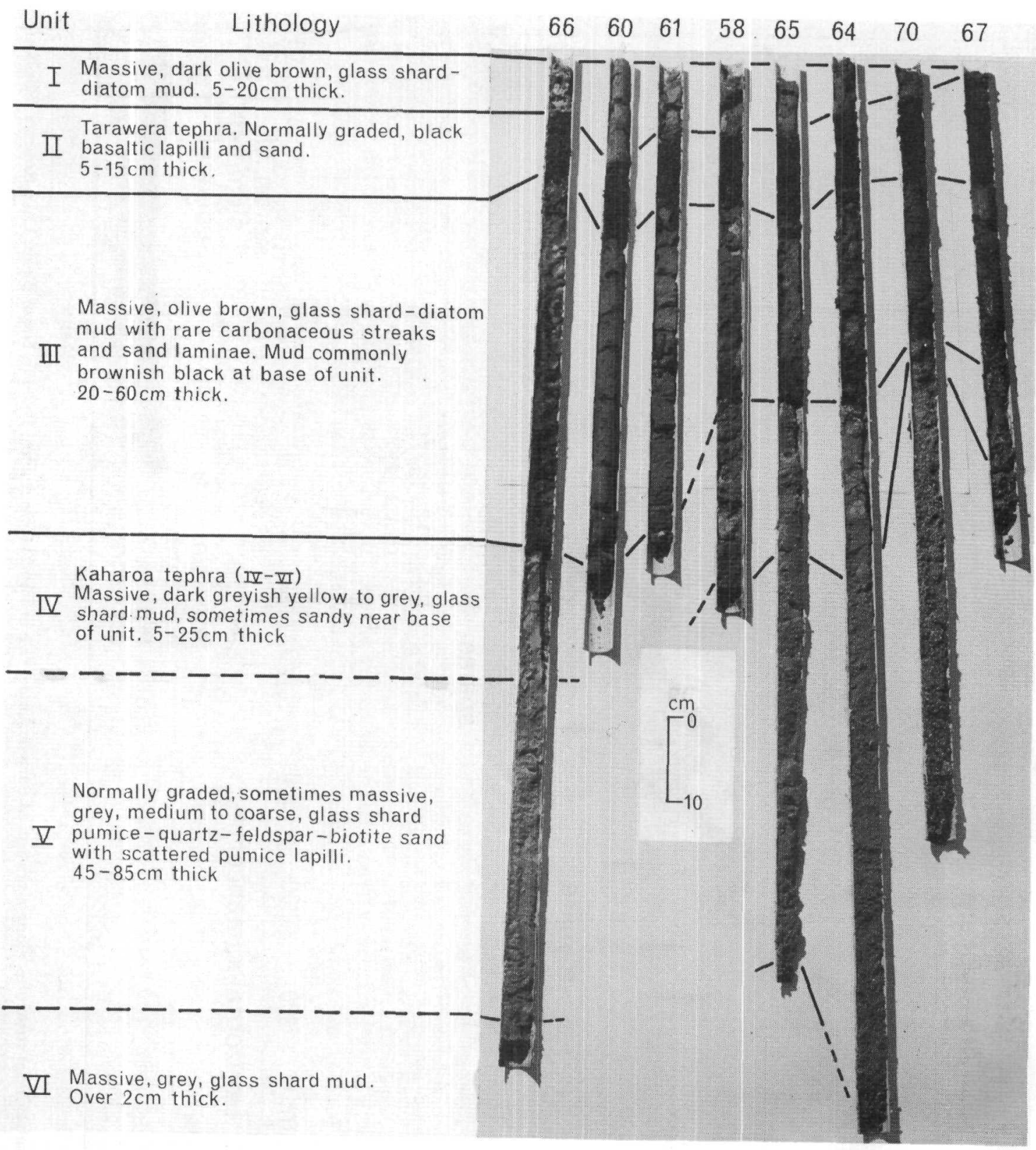
Fig. 13 Stratigraphy of drained sediment cores from basinal areas in Lake Rotoma. Small gaps resulting from
dewatering of the muddy sediment intervals havé been closed up.

storm waves are unlikely to affect the bottom below about 3-5 $\mathrm{m}$ depth, depending on degree of exposure. However, mixed sand-gravel substrates occur to depths of 15-25 m (Fig. 6 and 7), and these sediments are interpreted as predominantly relict littoral deposits formed during periods of lower lake level. Some nearshore profiles (Fig. 3) exhibit a low hummocky topography below wave base which may represent modified beach ridges, offshore bars, or plant-bound sediment mounds associated with lower lake levels. Many of the wide, west-facing sandy shelves show a prominent step at about $10 \mathrm{~m}$ depth (e.g., Transects 29, 32, and 38 in Fig. 3) which is reminiscent of a back-beach storm ridge or cliff line and may delimit a former, relatively prolonged stand of lake level a little below this depth. The 


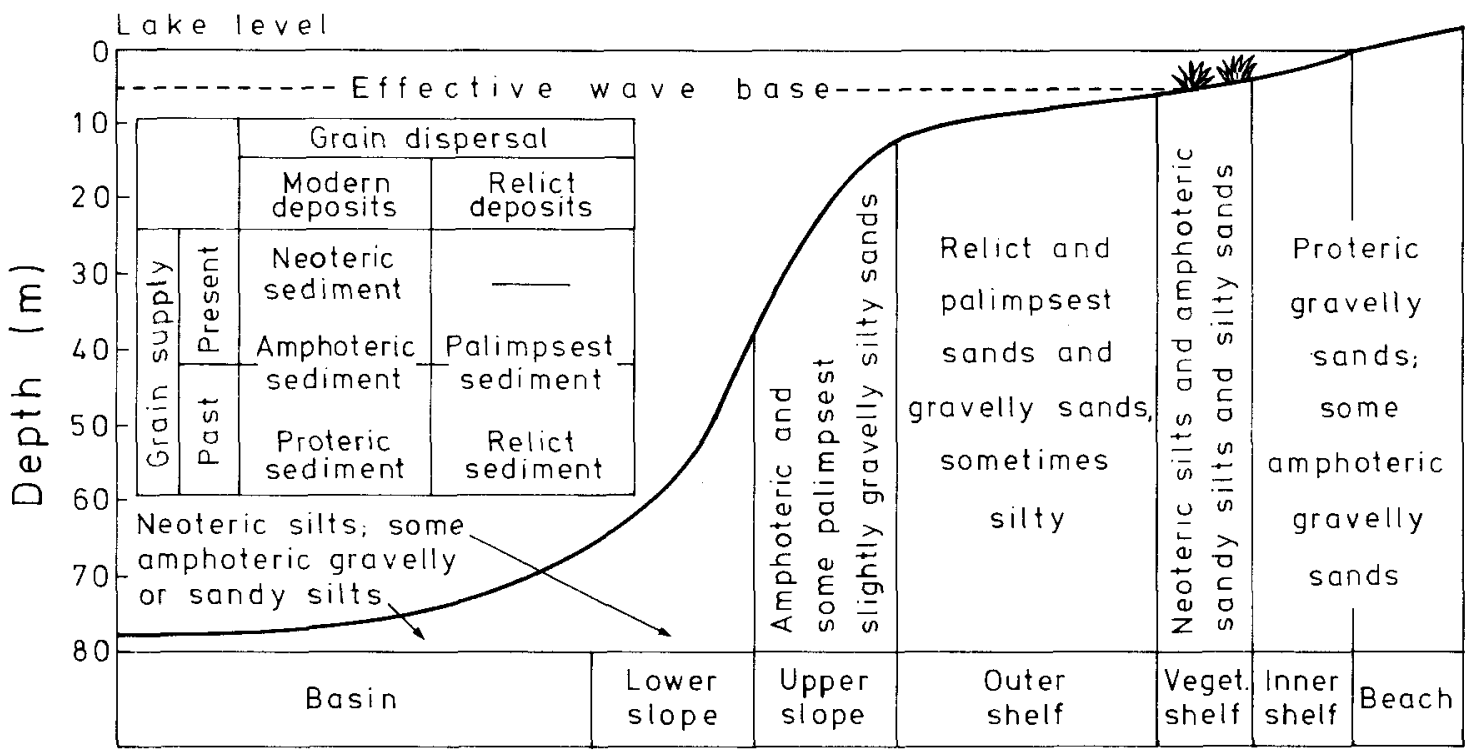

Fig. 14 Process-age surficial sediment categories in Lake Rotoma based on the different ages of supply and dispersal of grains. Concept adapted from McManus (1975) for sediments on oceanic continental shelves. His terminology is defined in the inset box.

strandline step is a sufficiently large-scale structure to be variably preserved during a subsequent rapid rise in lake level.

That muds are not blanketing these relict sand deposits indicates that the turbulence of waters from 5-25 m, which fall within and above the normal thermocline depth range (Table 1 ), is periodically sufficient to maintain fines in suspension. Resuspension of fine sediment by benthic organisms such as crayfish and mussels may be an additional contributing factor.

\section{Sediment process-age categories}

Oceanic continental shelves have experienced large glacio-eustatic fluctuations in sea level during the Quaternary, making the distinction between truly modern and relict shelf sediments a difficult one (e.g., Emery 1968; Swift et al. 1971). McManus (1975) showed the need for distinguishing between the concepts of grain supply and grain dispersal, as well as the time at which these processes operated, when defining modern and relict deposits. He erected 5 process-age sediment categories (Fig. 14, inset) which, while not appearing to have received wide acceptance in publication, can be usefully applied to describe the surficial sediment distribution patterns in Lake Rotoma, emphasising the polygenetic character and age of grains and deposits (Fig. 14). Thus, modern deposits occur in most lake environments except the outer shelf, and perhaps parts of the upper slope, and they can be differentiated according to the character and relative ages of their constitutent particles. Basinal and lower slope deposits are dominantly neoteric muds, composed mainly of vertically sedimented modern diatom frustules and some glass shards, but locally they are amphoteric gravelly or sandy muds incorporating coarse tephric fragments reworked by organisms into the diatomaceous muds from underlying tephras, particularly the Tarawera Ash and Lapilli, or introduced from upslope by gravity creep or slides. Modern deposits in the vegetated shelf environment are also mainly neoteric diatomaceous muds within denser tracts of submerged macrophytes, but are amphoteric sandy muds and muddy sands within less dense stands of aquatic vegetation, where they include a volcanogenic sand fraction supplied to the lake in the past. Littoral deposits above wave base, including the inner shelf and beach environments, consist mainly of proteric mixed gravel-sand sediments composed of coarse-grained volcanogenic particles supplied by air-fall and catchment sources at various times in the past. Only in local areas of active cliffline erosion are these deposits being diluted by truly modern terrigenous fragments, forming minor regions of amphoteric gravelly sands. The overdeepened outer shelf sands and gravelly sands below storm wave base are relict deposits; the modern 
dispersal processes cannot explain their formation. The bulk of these particles were supplied in the past, so that they are relict sediments, but the addition of small amounts of modern diatomaceous and volcanogenic silt dropped out of suspension would distinguish them as palimpsest sediments. The intermediate nature of the upper slope environment creates a rather complex zone characterised by various mixtures of modern and 'ancient' diatomacous and volcanogenic silts and 'ancient' volcanogenic sands. Mixing has been accomplished by bioturbation, spill-over of sand at the shelf edge, gravity slides, and currents associated with lakewater over-turn. Most likely amphoteric sediments dominate, but patches of palimpsest sediment probably occur higher on the slope.

\section{SUMMARY AND CONCLUSIONS}

1. Lake Rotoma is a deep (70-80 m), oligotrophic, warm-monomictic lake of volcanic origin with insignificant fluvial inflow and no clearly defined outflow. Over the 60-year period up to 1972 the water level has fluctuated markedly about a secular rising trend of some $6-10 \mathrm{~m}$.

2. Morphologic variations in nearshore profiles appear to be related to prevailing wave climate superimposed upon the overall rising lake level in historical times, the shelves (and their contiguous slopes) bordering the more exposed eastern (and southern) shoreline being wider, less steep, and extending into deeper water than their counterparts along much of the lower-energy western shoreline. The outer portions of shelves extending well below storm wave base into waters as deep as 15-25 m off exposed shorelines are relict features from low lake levels.

3. Surficial bottom sediments generally become finer with increasing water depth and several environment-related, roughly shoreline-parallel textural facies zones are defined: Facies 1 (beach)sandy gravels and gravelly sands; Facies 2a (open shelf)-gravelly sands and slightly gravelly sands; Facies $2 b$ (vegetated shelf)-silts and sandy silts; Facies 3a (upper slope)-slightly gravelly silty sands; Facies 3b (lower slope)-sandy silts; Facies 4 (basin)—silts.

4. A close relationship exists between sediment texture and composition. Gravel material consists exclusively of volcanic rock fragments of pumice, rhyolite, and scoriaceous basalt, the coarser sand fraction of the same rock fragments and plagioclase feldspar, the finer sand grades of plagioclase feldspar, quartz, and a variety of ferromagnesian minerals, the coarser silt fraction of glass shards, the finer silt fraction of diatom frustules and organic matter, and the clay fraction of allophane.
5. Pore waters are acidic $(\mathrm{pH}, 6.5-7)$ and moderately oxidising ( $\mathrm{Eh},+200$ to $+500 \mathrm{mV}$ ) in nearshore, organic-poor, coarse-grained sediments, but alkaline $(\mathrm{pH}, 7-8)$ and reducing $(\mathrm{Eh},<+200$ $\mathrm{mV}$ ) in offshore, organic-rich, fine-grained sediments, suggesting that the biochemical destruction of organic matter is influenced significantly by the permeability of the substrate.

6. The only source of modern terrigenous material in the lake is from localised cliff-line erosion in Late Pleistocene pumice breccias and from isolated slips in the Holocene ash cover on slopes about the lake. The bulk of the terrigenous sediment was supplied in the past by direct airfall of volcanic ejecta, and by slope wash and slips in the freshly deposited tephras about the shoreline. Tephric layers were preserved in offshore environments, but in nearshore zones were homogenised with earlier deposits by bioturbation and/or wave action. Contrasting with the infrequent periods of volcanic inputs is the slow rain of intralake diatom frustules and organic matter, concentrated in basinal and slope deposits by vertical sedimentation beneath the thermocline and in some nearshore areas by entrapment within stands of aquatic vegetation.

7. Cores in basinal areas include tephras from both the Tarawera (A.D. 1886) and Kaharoa (A.D. 1020) eruptions from Mt Tarawera, and suggest that deep-water sedimentation rates of diatomaceous silts have about doubled since the Tarawera eruption. The implied increase in the fertility level of lake waters may relate to farm development in the catchment.

8. Surficial bottom sediments in Lake Rotoma consist of grains of both biological and terrigenous origin, some of which are being supplied to the lake now, and others of which were supplied at various times in the past. Although many of these sediments occur in truly modern deposits, approaching equilibrium with the present hydraulic regime, others are relict deposits, associated with former lower lake levels. On this basis 5 process-age lacustrine sediment categories can be erected, namely neoteric, amphoteric, proteric, palimpsest, and relict sediments, analogous to those that have been defined on oceanic continental shelves.

\section{ACKNOWLEDGMENTS}

I thank Messrs L. J. Gaylor and M. J. Vennard (Department of Earth Sciences) and Messrs N. W. Rogers and M. D. Buck (Earth Sciences post-graduates, 1975-77) for field assistance; $\mathrm{Mr}$ J. Irwin and Dr R. A. Pickrill (New Zealand Oceanographic Institute) for the Raytheon subbottom profiles; Dr C. K. Beltz (University of Waikato) for identifying the major diatom types; Dr J. S. Clayton (Ministry of Agriculture and Fisheries, Ruakura) for permission to use data from his thesis; and $\mathrm{Mr} \mathbf{R}$. J. Pittams (Ministry of Works and Development, Hamilton) 
for access to unpublished results. Dr D. Rogers (Hamilton) kindly provided lake-side accommodation. The paper benefited from critical reading by Dr A. P. W. Hodder (Department of Earth Sciences) and Dr G. R. Fish (Ministry of Agriculture and Fisheries, Rotorua), and especially from comments provided by an unknown referee. The manuscript was prepared while I was on leave at the Department of Geological Sciences, University of British Columbia, Canada, and the facilities made available there are gratefully acknowledged.

\section{REFERENCES}

Anonymous 1972: Factors affecting lake levels in the Rotorua area. Unpublished report, Freshwater Section, Ecology Division, DSIR, Taupo.

Brown, J. M. A. 1975: Ecology of macrophytes. In: Jolly, V. H.; Brown, J. M. A. ed., New Zealand lakes. Auckland, Auckland University Press and Oxford University Press, p. 224-262.

Cassie, Vivienne 1978: Seasonal changes in phytoplankton densities in four North Island lakes, 1973-74. New Zealand journal of marine and freshwater research $12: 153-166$.

Chapman, V. J.; Coffey, B. T.; Brown, J. M. A. 1971: Submerged vegetation of the Rotorua and Waikato lakes. 2. 'Cyclic change' in Lake Rotoiti. New Zealand journal of marine and freshwater research 5: $461-482$.

Clayton, J. S. 1978: The submerged vegetation of Lake Rotoma. Unpublished Ph.D. thesis, University of Auckland, Auckland, New Zealand.

Cole, J. W. 1970a: Description and correlation of Holocene volcanic formations in the TaraweraRerewhakaaitu region. Transactions of the Royal Society of New Zealand, earth sciences, $8: 92-108$.

1970b: Structure and eruptive history of the Tarawera volcanic complex. New Zealand joumal of geology and geophysics $13: 879-902$.

Craig, G. C.; Nelson, C. S. 1981: Bottom sediments of Lake Rotoiti. Geological Society of New Zealand Hamilton conference, Programme and Abstracts. p. 28.

Davis, R. B. 1974: Stratigraphic effects of tubifiuds in profundal lake sediments. Limnology and oceanography $19: 466-488$.

Emery, K. O. 1968: Relict sediments on continental shelves of the world. American Association of Petroleum Geologists bulletin $52: 445-464$.

Ewart, A. 1966: Review of mineralogy and chemistry of the acidic volcanic rocks of Taupo volcanic zone, New Zealand. Bulletin volcanologique 29 : 147-171.

Fish, G. R. 1970: A limnological study of four lakes near Rotorua. New Zealand journal of marine and freshwater research 4: 165-194.

1979: Recent stratigraphy of sediments in Lake Rotorua. New Zealand journal of marine and freshwater research $13: 529-532$.

Flint, E. A. 1975: Phytoplankton in some New Zealand lakes. In: Jolly, V. H.; Brown J. M. A. ed., New Zealand lakes. Auckland, Auckland University Press and Oxford University Press, p. 163-192.

1977: Phytoplankton in seven monomictic lakes near Rotorua, New Zealand. New Zealand journal of botany $15: 197-208$.
Folk, R. L. 1968: Petrology of sedimentary rocks. Austin, Texas, Hemphills.

Folk, R. L.; Ward, W. C. 1957: Brazos River bar: a study in the significance of grain size parameters. Joumal of sedimentary petrology $27: 3-26$.

Gee, F. 1960: Rotorua trout--the fishing lakes, rivers and streams of the Rotorua Conservancy, New Zealand. Wellington, A. H. \& A. W. Reed.

Glasby, G. P. 1973: Interstitial waters in marine and lacustrine sediments: a review. Joumal of the Royal Society of New Zealand 3: 43-59.

Grange, L. T. 1937: The geology of the Rotorua-Taupo Subdivision. New Zealand Geological Survey bulletin 37.

Healy, J. 1975: Volcanic lakes. In: Jolly, V. H.; Brown, J. M. A. ed., New Zealand lakes. Auckland, Auckland University Press and Oxford University Press, p. 70-83.

Healy, J.; Schofield, J. C.; Thompson, B. N. 1964: Sheet 5 Rotorua (1st ed.). Geological Map of New Zealand 1:250 000. Wellington, DSIR.

Howard, R. K. 1971: Flooding Lakes Rotoma and Rotoehu. Unpublished report to Soil Conservation and Rivers Control Council, Bay of Plenty Catchment Commission.

Howorth, R. 1975: New formations of Late Pleistocene tephras from the Okataina Volcanic Centre, New Zealand. New Zealand joumal of geology and geophysics $18: 683-712$.

Irwin, J. 1967: Lake Rotoma. Provisional bathymetry, 1:15 840. Fisheries Research Division, Lake Series.

1975: Morphology and classification. In: Jolly, V. H.; Brown, J. M. A. ed., New Zealand lakes. Auckland, Auckland University Press and Oxford University Press, p. 25-56.

Jolly, V. H.; Brown, J. M. A. ed. 1975: New Zealand lakes. Auckland, Auckland University Press and Oxford University Press.

Jolly, V. H.; Irwin, J. 1975: Thermal conditions. In: Jolly, V. H.; Brown, J. M. A. ed., New Zealand lakes. Auckland, Auckland University Press and Oxford University Press, p. 90-105.

Jordan, C. F.; Fryer, G. E.; Hemmen, E. H. 1971: Size analysis of silt and clay by hydrophotometer. Journal of sedimentary petrology $41: 489-496$.

Kamp, P. J. J. 1979: Computer processing of earth materials data. Department of Earth Sciences, University of Waikato, Occasional report no. 4.

Kirkman, J. H. 1976: Clay mineralogy of 13 paleosols developed in Holocene and Late Pleistocene tephras of Central North Island, New Zealand. New Zealand journal of geology and geophysics 19 : $179-187$.

Kohn, B. P.; Glasby, G. P. 1978: Tephra distribution and sedimentation rates in the Bay of Plenty, New Zealand. New Zealand journal of geology and geophysics 21 : $49-70$.

Lawless, J. V. 1975: The geology of the Cashmores Road perlite occurrence, Atiamuri. Unpublished M.Sc. thesis, University of Waikato, Hamilton, New Zealand.

Lister,G. S. 1978: Sedimentology of Lake Taupo, Central North Island, New Zealand. Unpublished M.Sc. thesis, University of Waikato, Hamilton, New Zealand. 
McColl, R. H. S. 1972: Chemistry and trophic status of seven New Zealand lakes. New Zealand journal of marine and freshwater research $6: 399-447$.

1974: Rotorua lakes. In: New Zealand's nature heritage 9. Auckland, Hamlyn House Books, p. $1200-1208$.

1975: Chemical and biological conditions in lakes of the Volcanic Plateau. In: Jolly, V. H.; Brown, J. M. A. ed., New Zealand lakes. Auckland, Auckland University Press and Oxford University Press, p. 123-139.

1977: Chemistry of sediments in relation to trophic condition of 8 Rotorua lakes. New Zealand journal of marine and freshwater research 11: 509-523.

McManus, D. A. 1975: Modern versus relict sediment on the continental shelf. Geological Society of America bulletin $86: 1154-1160$.

Main, W. de L. 1976: Morphology of Lake Waikaremoana, New Zealand, and reconnaissance of its benthic fauna. New Zealand journal of marine and freshwater research 10:597-611.

Mitsui, K.; Taguchi, K. 1977: Silica mineral diagenesis in Neogene Tertiary shales in the Tempoku district, Hokkaido, Japan. Joumal of sedimentary petrology $47: 158-167$.

New Zealand Meteorological Service 1975-1977: Meteorological observations for $1975-1977$. New Zealand Meteorological Service miscellaneous publication 109. Wellington, Ministry of Transport.
Passega, R. 1964: Grain size representation by CM patterns as a geological tool. Joumal of sedimentary petrology $34: 830-847$.

Phillips, C. J.; Nelson, C. S. 1981: Sedimentation in an artificial lake-Lake Matahina, Bay of Plenty. New Zealand joumal of marine and freshwater research $15: 459-473$.

Pickrill, R. A. 1978: Beach and nearshore morphology of Lakes Manapouri and Te Anau, New Zealand: natural models of the continental shelf. New Zealand journal of geology and geophysics 21 : $229-242$.

Stumm, W.; Baccini, P. 1978: Man-made chemical perturbation of lakes. In: Lerman, A. ed., Lakes: chemistry, geology, physics. New York, SpringerVerlag, p. $91-126$.

Swift, D. J. P.; Stanley, D. J.; Curray, J. R. 1971: Relict sediments on continental shelves: a reconsideration. Joumal of geology 19 : $322-346$.

Visher, G. S. 1969: Grain size distributions and depositional processes. Journal of sedimentary petrology 39 : $1074-1106$.

Vucetich, C. G.; Pullar, W. A. 1964: Stratigraphy and chronology of the late Quaternary volcanic ash in Taupo, Rotorua and Gisborne districts. Part 2. New Zealand Geological Survey bulletin 73.

White, E.; Don, Beverley J.; Downes, M. T.; Kemp, Linda J.; MacKenzie, A. L.; Payne, G. W, 1978: Sediments of Lake Rotorua as sources and sinks for plant nutrients. New Zealand journal of marine and freshwater research 12: $121-130$. 